\title{
MORPHOLOGICAL VARIABILITY AND SEXUAL DIMORPHISM OF STONE CRAYFISH Austropotamobius torrentium FROM THE MARJANOVIĆA STREAM (BOSNIA AND HERZEGOVINA)
}

\author{
Rajko Roljićc ${ }^{*}$, Vera Nikolić ${ }^{2}$, Nebojša Savićc \\ ${ }^{1}$ University of Banja Luka, Genetic Resources Institute, \\ Bulevar Vojvode Petra Bojovića 1A, 78000 Banja Luka, Republic of Srpska, \\ Bosnia and Herzegovina \\ ${ }^{2}$ University of Belgrade, Faculty of Biology, \\ Studentski trg 16, 11000 Beograd, Republic of Serbia \\ ${ }^{3}$ University of Banja Luka, Faculty of Agriculture, \\ Bulevar Vojvode Petra Bojovića 1A, 78000 Banja Luka, Republic of Srpska, \\ Bosnia and Herzegovina \\ *Corresponding author; E-mail: rajkoroljic@gmail.com \\ (Received September 2, 2019; Accepted December 7, 2019)
}

\begin{abstract}
This paper presents the first information about the morphological variability and sexual dimorphism of the stone crayfish Austropotamobius torrentium in the area of Marjanovića Stream in Čelinac (Republic of Srpska, Bosnia and Herzegovina). The crayfish were caught by hand-made made baited traps from October 2018 to May 2019. A total of 67 specimens were caught, out of which 33 males and 34 females. The eight morphometric characteristics - body weight (W), body length (TBL), claw length (CLL), carapace length $(\mathrm{CPW})$, carapace width $(\mathrm{CPW})$, abdomen length $(\mathrm{ABL})$, rostrum length (ROL) and rostrum width (ROW) were analyzed for all specimens and the results were partially matched into the already known range of variations. Also, the body condition was determined for all individuals. By using the t-test, the significant differences between the sexes for W, TBL, CLL, CPW and ABL were registered, which could be explained by the sexual dimorphism of the stone crayfish.
\end{abstract}

Keywords: stone crayfish, morphometric characteristics, sexual dimorphism, Marjanovića Stream.

\section{INTRODUCTION}

The morphometric features of crayfish are the basic criteria for specifying their taxonomic status. Precise crayfish taxonomy involves the application of these, combined with morphological, anatomical, cytogenetic, biochemical, physiological, ecological, evolutionary 
and other methods (VUKOVIĆ et al., 1978). A study of morphometric features of the crayfish populations from various water ecosystems with the aim to determine their systematic position and status was conducted by numerous authors, such as TROŽIĆ-BOROVAC et al. (2007), TROŽIĆ-BOROVAC (2012) and RAJKOVIĆ (2012). MAGUIRE (2010) and it emphasizes the importance of research of morphometric features variability in species from the Astacus and Austropotamobius genera in order to produce an efficient key for lover taxa determination, given the present difficulties in determination thereof.

There is a lack of information available on the values of morphometric features for the stone crayfish Austropotamobius torrentium (Schrank, 1803) populations from numerous places within its distribution area. Stone crayfish exist only in cold mountain waters, where, probably due to its modest needs, it took over a dominant role (OBRADOVIĆ, 1988). This crayfish species is dominant in Bosnia and Herzegovina (TrOŽIĆ-BOROVAC, 2011) and neighboring countries such as Serbia (SIMIĆ et al., 2008), Croatia (MAGUIRE and GotTSTEINMATOČEC, 2004) and Montenegro (RAJKOVIĆ, 2012).

The aim of an earlier study was to determine the principal morphometric features, the body weight, the Fulton's condition factor and the length-weight relationship of decapod crustaceans in the Austropotamobius torrentium population from the Korana river. According to IUCN criteria the latter was assigned the DD (Data Deficient) category for the European region (FÜREDER et al., 2010), and it is listed on the national Red List of Bosnia and Herzegovina as endangered species VU (Vulnerable).

This study aims are to determine whether there are differences between the morphometric features of males and females and to consider the condition of the captured individuals in order to estimate the possible anthropogenic pressure on the population of stone crayfish in Marjanovića Stream in Čelinac (Republic of Srpska, Bosnia and Herzegovina).

\section{MATERIALS AND METHODS}

Downstream from Čelinac (Republic of Srpska, Bosnia and Herzegovina) at the beginning of a gorge named Donja Vrbanja, the location known as Marjanovići, the Marjanovića Stream flows into the Dolinski Stream. The source location is on the western slopes of Stara Brda (altitude of $510 \mathrm{~m}$ ) and the mouth in the Dolinski Stream is downstream from the village Marjanovići, at the altitude of $210 \mathrm{~m}$. The total flow length is $2.58 \mathrm{~km}$ (RAJČEVIĆ and CRNOGORAC, 2011). A riverbed is originally preserved and is sometimes used for irrigation in the upper and middle watercourse of the Marjanovića stream. It belongs to watercourses that need to be ecologically evaluated.

The nets and LiNi trap with baits (WESTMAN et al., 1978) were used to collect stone crayfish specimens from October 2018 to May 2019. Given that the traps for crayfish hunting are selective for the size of the specimen (HOGGER, 1988), almost all hunted specimens were larger than $70 \mathrm{~mm}$. All specimens were caught at twilight, between 06:00 p.m. and 10:00 p.m. and the specimens were identified according to the key provided by MAGUIRE (2010), with the help of SOUTY-GROSSET et al. (2006) atlas.

The values of the main morphometric features were determined in all evaluated specimens: total body length (TBL), claw length (CLL), carapace length (CPL), carapace width (CPW), abdomen length (ABL), rostrum length (ROL) and rostrum width (ROW). In addition, the values of body weight (W) are determined, and two condition indices (adopted from STREISSL and HöLD, 2002) were calculated:

$$
\text { Fulton's Conditions Factor (FCF) } \quad F C F=\frac{W}{T B L^{3}}
$$

where $\mathrm{W}$ - total weight, TBL - total body length, and 


\section{Crayfish Constant (CC)}

$$
C C=\frac{W}{T B L \times C P L \times C P W}
$$

where $\mathrm{W}$ - total weight, TBL - total body length, $\mathrm{CPL}$ - carapace length, and CPW - carapace width.

For the body weight determination, a weighing scale of type "Kern" (Kern PFB Version 2.2) max. weighting $1200 \mathrm{~g}$ with an accuracy of $0.01 \mathrm{~g}$ is used, while morphometric measures were taken using a caliper gauge (made by Stainless Hardened) with an accuracy of $0.02 \mathrm{~mm}$. Collected data are processed by using Microsoft Office Excel and Statistic 5.

\section{RESULTS}

Out of a total of 67 analysed stone crayfish specimens from the Marjanovića Stream it was found that 33 (or $49.25 \%$ ) were males, and 34 (or 50.75\%) were females (sex ration close to $1: 1)$.

Measurement results of morphometric parameters of specimens are presented in tables 1-3 as mean value, minimum (min), maximum (max), standard deviation (SD) and coefficient of variation (CV). The results are shown for all specimen jointly (Tab. 1), and separately for males (Tab. 2) and females Tab. 3).

The average values of measured characteristics obtained for all of the analyzed specimens (Tab. 1) show that the body weight is $22.37 \mathrm{~g}$, the body length is $98.74 \mathrm{~mm}$, the claw length is $33.03 \mathrm{~mm}$, the cephalothorax length is $45.68 \mathrm{~mm}$, the carapace width is $29.5 \mathrm{~mm}$, the abdomen length is $35.41 \mathrm{~mm}$, the rostrum length is $10.41 \mathrm{~mm}$, and rostrum width is $7.9 \mathrm{~mm}$. Based on these values, the SD is obtained and has the highest value for body length (9.97) and body weight (8.24), slightly smaller it is for the claw length (7.61), the cephalothorax length (4.72) and width (3.56) and the abdomen length (4.72), even smaller for the rostrum length (1.43), while the smallest is for the rostrum width (0.97). We can conclude that five (TBL, CPL, $\mathrm{ABL}, \mathrm{ROL}, \mathrm{ROW})$ of seven tested morphometric features fall into a low variable (CV 10 $20 \%$ ). The moderately variable (CV 20-30\%) is CLL, while only one morphometric feature, $\mathrm{W}$, shows high variability $(\mathrm{CV}>30 \%)($ Tab. 1$)$.

Table 1. Descriptive statistics - mean value and ranges of measured characteristics*, standard deviation (SD) and coefficient of variation (CV),

for all of 67 specimens of Austropotamobius torrentium from the Marjanovića Stream.

\begin{tabular}{lcccccccc}
\hline $\begin{array}{l}\text { Statistical } \\
\text { parameters }\end{array}$ & W & TBL & CLL & CPL & CPW & ABL & ROL & ROW \\
\hline Mean & 22.37 & 98.74 & 33.03 & 45.68 & 29.50 & 35.41 & 10.41 & 7.90 \\
Min & 6.60 & 69.48 & 19.58 & 30.36 & 20.18 & 25.21 & 6.05 & 5.00 \\
Max & 46.00 & 117.9 & 52.50 & 56.49 & 37.10 & 43.96 & 13.50 & 10.36 \\
SD & 8.24 & 9.97 & 7.61 & 4.82 & 3.56 & 4.72 & 1.43 & 0.97 \\
CV & 36.90 & 10.09 & 23.05 & 10.55 & 12.08 & 13.33 & 13.72 & 12.22 \\
\hline
\end{tabular}

* body weight (W), total body length (TBL), claw length (CLL), carapace length (CPL), carapace width (CPW), abdomen length (ABL), rostrum length (ROL) and rostrum width (ROW).

The obtained values for males show that on average, the body weight is $28 \mathrm{~g}$, the body length is $104.01 \mathrm{~mm}$, the claw length is $38.47 \mathrm{~mm}$, the cephalothorax length is $47.96 \mathrm{~mm}$, the carapace width is $31.75 \mathrm{~mm}$, the abdomen length is $37.1 \mathrm{~mm}$, the rostrum length is $10.55 \mathrm{~mm}$ and the rostrum width is $8.1 \mathrm{~mm}$. On the basis of these values, the SD is obtained which has the 
highest value for the body length (8.86), slightly smaller is for the weight (6.95), the claw length (6.56), the abdomen length (4.31), the cephalothorax length (4.22) and cephalothorax width (3.22), while the lowest value is for the rostrum length (1.62) and the rostrum width (0.91). According to the analysis of the morphometric features, fixed features $(\mathrm{CV}<10 \%)$ are TBL and CPL. In males (with the coefficient of variation CV 10-20\%) moderately variable characteristics are CLL, CPW, ABL, ROL and ROW. The moderately variable feature (CV 20$30 \%$ ) is only the $\mathrm{W}$ (24.82) (Tab. 2).

Table 2. Descriptive statistics - mean value and ranges of measured characteristics*, standard deviation (SD) and coefficient of variation $(\mathrm{CV})$,

for 33 males of Austropotamobius torrentium from the Marjanovića Stream.

\begin{tabular}{lcccccccc}
\hline \multirow{2}{*}{$\begin{array}{l}\text { Statistical } \\
\text { parameters }\end{array}$} & W & TBL & CLL & CPL & CPW & ABL & ROL & ROW \\
\hline Mean & 28.00 & 104.01 & 38.47 & 47.96 & 31.75 & 37.10 & 10.55 & 8.10 \\
Min & 12.00 & 82.64 & 21.40 & 36.00 & 24.00 & 29.18 & 6.05 & 6.20 \\
Max & 46.00 & 117.90 & 52.50 & 56.49 & 37.10 & 43.96 & 13.50 & 10.36 \\
SD & 6.95 & 8.86 & 6.56 & 4.22 & 3.22 & 4.31 & 1.62 & 0.91 \\
CV & 24.82 & 8.52 & 17.06 & 8.80 & 10.15 & 11.61 & 15.37 & 11.21 \\
\hline
\end{tabular}

* body weight (W), total body length (TBL), claw length (CLL), carapace length (CPL), carapace width $(\mathrm{CPW})$, abdomen length (ABL), rostrum length (ROL) and rostrum width (ROW).

The obtained values for females show that the average body weight is $16.67 \mathrm{~g}$, the average body length is $93.47 \mathrm{~mm}$, the claw length $27.58 \mathrm{~mm}$, the cephalothorax length is 42.25 $\mathrm{mm}$, the carapace width is $27.26 \mathrm{~mm}$, the abdomen length $33.71 \mathrm{~mm}$, the rostrum length is $10.27 \mathrm{~mm}$ and the rostrum width is $7.7 \mathrm{~mm}$. Based on these values, the SD has the highest value for the body length (8.12), slightly smaller value for the body weight (4.85), the abdomen length (4.56), the claw length (3.66), the cephalothorax length (3.48), the cephalothorax width (2.34), while the least value is for the rostrum length (1.21) and the rostrum width (0.99). Three of the observed morphometric features are fixed features $(\mathrm{CV}<10 \%)$, the four analyzed morphometric features are moderately variable (CV $10-20 \%$ ), while the only one morphometric feature $\mathrm{W}$ $(\mathrm{CV}=29.11 \%)$ is moderately variable (CV $20-30 \%)$ (Tab. 3).

Table 3. Descriptive statistics - mean value and ranges of measured characteristics*, standard deviation (SD) and coefficient of variation (CV),

for 34 females of Austropotamobius torrentium from the Marjanovića Stream.

\begin{tabular}{lcccccccc}
\hline $\begin{array}{l}\text { Statistical } \\
\text { parameters }\end{array}$ & W & TBL & CLL & CPL & CPW & ABL & ROL & ROW \\
\hline Mean & 16.67 & 93.47 & 27.58 & 42.25 & 27.26 & 33.71 & 10.27 & 7.70 \\
Min & 6.60 & 69.48 & 19.58 & 30.36 & 20.18 & 25.21 & 8.05 & 5.00 \\
Max & 28.60 & 114.37 & 37.24 & 47.87 & 30.48 & 41.91 & 12.94 & 9.50 \\
SD & 4.85 & 8.12 & 3.66 & 3.48 & 2.24 & 4.56 & 1.21 & 0.99 \\
CV & 29.11 & 8.68 & 13.27 & 8.23 & 8.22 & 13.53 & 11.80 & 12.91 \\
\hline
\end{tabular}

* body weight (W), total body length (TBL), claw length (CLL), carapace length (CPL), carapace width (CPW), abdomen length (ABL), rostrum length (ROL) and rostrum width (ROW).

Males and females differ significantly in statistical terms $(\mathrm{p}<0.0001)$ in five analyzed morphometric features: $\mathrm{W}(\mathrm{p}=0.0001)$, TBL $(\mathrm{p}=0.0001)$, CLL $(\mathrm{p}=0.0001)$, CPW $(\mathrm{p}=$ $0.0001)$, and ABL $(p=0.0037)$. There is no statistically significant difference $(p>0.05)$ for ROL $(p=0.582)$ and ROW $(p=0.129)($ Tab. 4). By comparing the mean values of the rostrum 
width and length among the sexes, the stone crayfish males have a higher mean value compared to females, but that difference is not significant in statistical terms.

Table 4. Significance of differences between mean values of morphometric characteristics between males and females of Austropotamobius torrentium from the Marjanovića Stream.

\begin{tabular}{cccc}
\hline $\begin{array}{c}\text { Measured } \\
\text { characteristics* }\end{array}$ & $\mathbf{p}$ & $\begin{array}{c}\text { Measured } \\
\text { characteristics }\end{array}$ & $\mathbf{p}$ \\
\hline W & $\mathbf{0 . 0 0 0 1}$ & CPW & $\mathbf{0 . 0 0 0 1}$ \\
TBL & $\mathbf{0 . 0 0 0 1}$ & ABL & $\mathbf{0 . 0 0 3 7}$ \\
CLL & $\mathbf{0 . 0 0 0 1}$ & ROL & 0.5820 \\
CPL & $\mathbf{0 . 0 0 0 1}$ & ROW & 0.1290 \\
\hline
\end{tabular}

* body weight $(\mathrm{W})$, total body length (TBL), claw length (CLL), carapace length (CPL).

In the course of statistical data processing, the correlation between total body length and weight for males $(64.54 \%)$ and females $(63.08 \%)$ is determined (Fig. 1). It shows that the body weight increases as the body length increases.
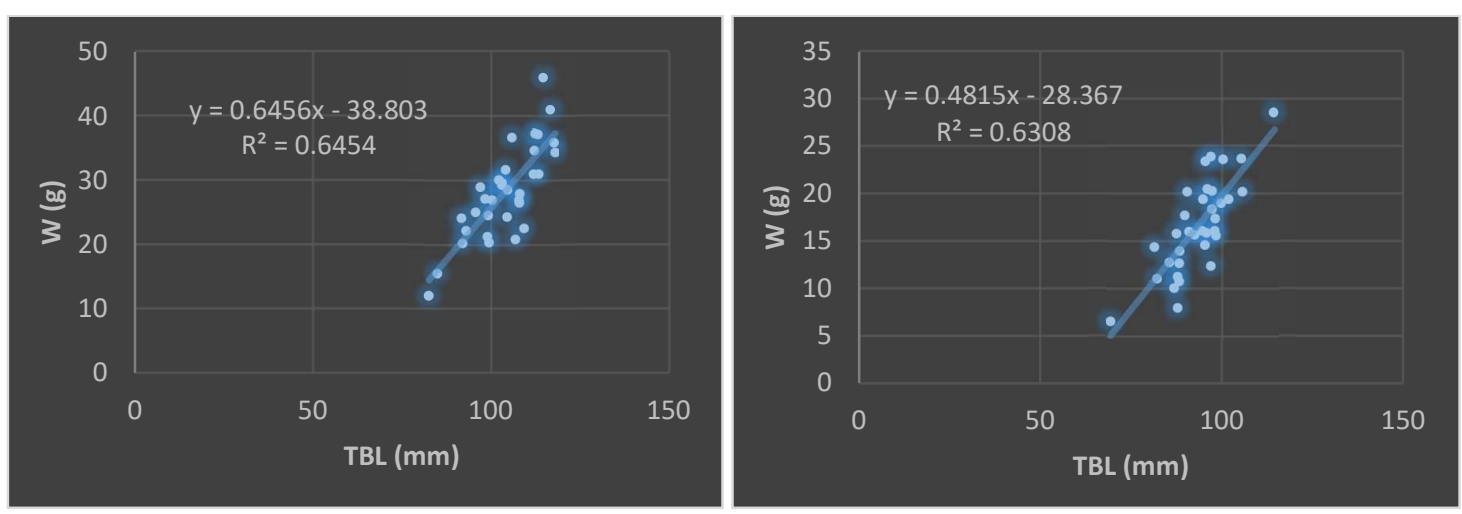

Figure 1. The correlation between total body length (TBL) and body weight (W) of males (left) and females (right) of Austropotamobius torrentium from the Marjanovića Stream.

The correlation between body weight and claw length the in both males and females is determined, and we notice a positive correlation, which means that the claw growth accompanies the body weight. The correlation coefficient in males is $67.65 \%$, and in females it is $61.70 \%$ (Fig. 2).
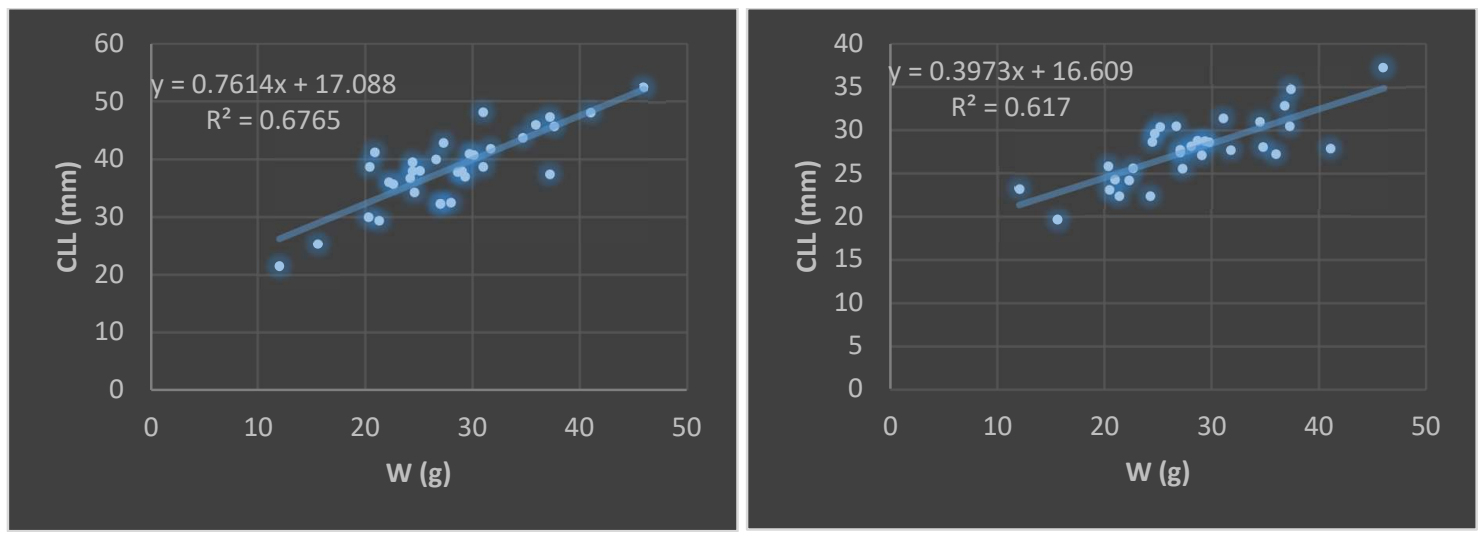

Figure 2. The correlation between body weight (W) and claw length (CLL) of males (left) and females (right) of Austropotamobius torrentium from the Marjanovića Stream. 
Based on the correlation coefficient obtained by applying regression analysis, it is observed that the coefficient is highly significant in statistical terms between the total body length (TBL) and the carapace width (CPW) - for males it is $70.39 \%$, while for females $87.43 \%$ (Fig. 3).
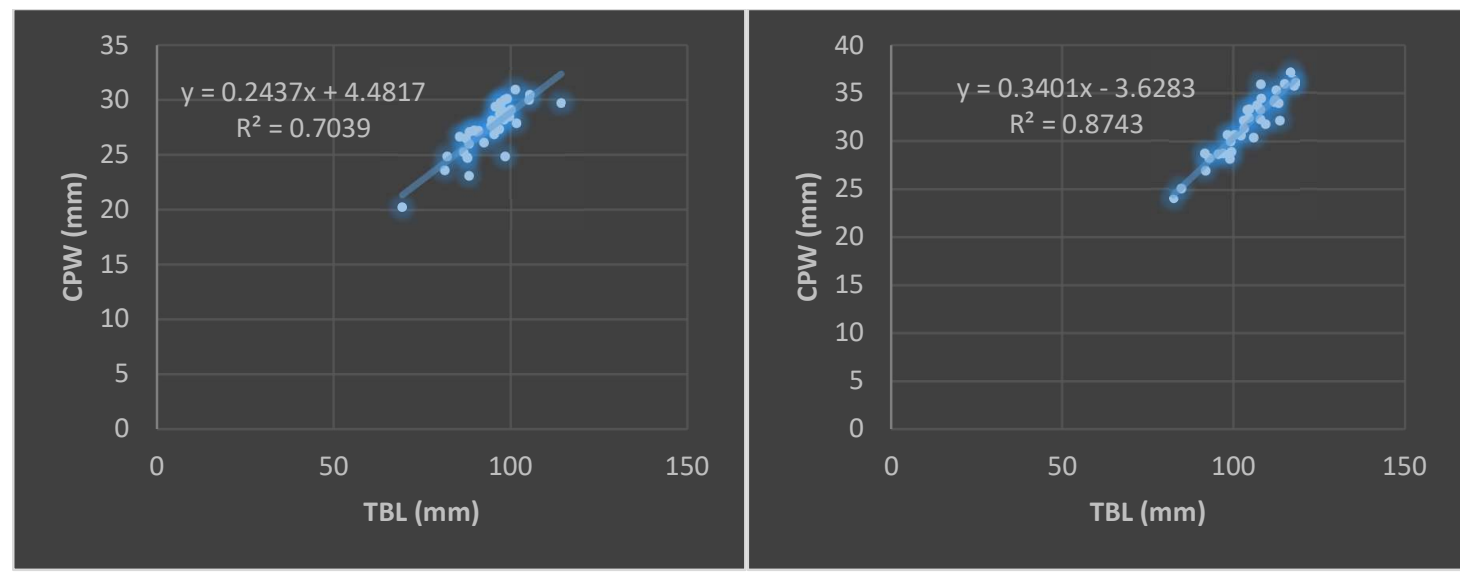

Figure 3. The correlation between total body length (TBL) and carapace width (CPW) of males (left) and females (right) of Austropotamobius torrentium from the Marjanovića Stream.

Considering the calculated condition factors (Tab. 5), the lowest value of FCF is 0.007 , for one female, while the highest (0.066) is for one male specimen. The mean FCF value for all males is 0.026 and for females 0.021 . The calculated CC varied from the lowest (only 0.074) for one female, to the highest $(0.521)$ for one male specimen. The mean value for females is 0.156 , while for males it is 0.185 .

Table 5. Ranges and mean value of condition factors FCF and CC, their standard deviation (SD) and coefficient of variation (CV) for males (M) and females (F) of Austropotamobius torrentium from the Marjanovića Stream.

\begin{tabular}{lccccc}
\hline & \multicolumn{5}{c}{ Fulton's Conditions Factor (FCF) } \\
\hline Sex & Min & Max & Mean & SD & CV \\
\hline M & 0.011 & 0.066 & 0.026 & 0.011 & 40.14 \\
F & 0.007 & 0.058 & 0.021 & 0.012 & 55.59 \\
\hline \multicolumn{5}{c}{ Crayfish Constant } & (CC) \\
\hline Sex & Min & Max & Mean & SD & CV \\
\hline M & 0.078 & 0.521 & 0.185 & 0.076 & 41.40 \\
F & 0.074 & 0.290 & 0.156 & 0.060 & 38.15 \\
\hline
\end{tabular}

\section{DISCUSSION}

Total sex ratio is balanced if the ratio between male and female is almost 1:1 (LEVIS, 2002). Having information on the sex ratio in population is significant as the uniform sex ratio mirrors healthy and stable population (JURKOVIĆ, 2016). In our results obtained from 67 stone crayfishes', specimens collected in 2018 and 2019 in the Marjanovića Stream, the sex ratio (M :F) is $1: 1.03$ (33 males : 34 females). Based on these results, we may conclude that a stable population exists in the observed location.

The population of stone crayfish of the species A. torrentium in the explored locality has a relatively stable age structure. At the explored location on the Marjanovića Stream, the 
largest group was $81-100 \mathrm{~mm}$ with $30.51 \%$. The longest length of the male body length was $117.9 \mathrm{~mm}$ and the longest length of the female body length was $114.37 \mathrm{~mm}$. Our results correspond to the range from $60-90 \mathrm{~mm}$ for female body length and $80-100.5 \mathrm{~mm}$ for male which are body length mentioned in literature (LAURENT, 1988), as well as to the values recorded by MAGUIRE et al. (2002), TROŽIĆ-BOROVAC et al. (2007) and RAJKOVIĆ (2012). The highest weight of the male body was $46 \mathrm{~g}$, while the highest weight of the female was $28.6 \mathrm{~g}$. The higher average male weight can be attributed to the fact that male has bigger claws, which contributes to their higher body weight compared to female (JURKOVIĆ, 2016).

Morphometric features of male and female from the species A.torrentium from the Marjanovića Stream differ in statistical terms $(\mathrm{p}<0.05)$, where higher average values are noticed for most males (Table 4). The obtained results can be correlated with the expressed sex dimorphism of stone crayfish from this species, where males are bigger than females (TROžIĆBOROVAC et al., 2007; RAJKOVIĆ, 2012).

According to the values of the calculated indices, it is evident that males are in a better condition than females. Similar data on the values of the conditional factor is provided by the studies conducted on adult males and females of the species $A$. torrentium (TrOžIĆ-BorOVAC et al., 2007).

\section{CONCLUSION}

Morphometric characteristics of stone crayfish Austropotamobius torrentium were observed from the Marjanović Stream in Čelinac (Republic of Srpska, Bosnia and Herzegovina) for the first time.

Eight morphometric characters and two condition factors were analyzed on captured 67 specimens ( 33 males and 34 females). The obtained values of the morphometric characters of stream crayfish on the studied locality partially fit into a known range of variability. The existence of statistically significant differences among adult sizes in the body mass, the total length of the body, the length of the claw, the length of the carapace, the width of the carapace, the length of the abdomen and the length of the rostrum in males compared to females is confirmed, which is explained by the sexual dimorphism of crustaceans.

The data presented in this paper can serve as a basis for further research of the populations of $A$. torrentium in this area.

\section{Acknowledgments}

The paper presents the result achieved by realization of Program for the conservation and sustainable use of genetic resources of Republic of Srpska, financed by the Ministry for Scientific and Technological Development, Higher Education and Information Society of the Republic of Srpska and implemented by the Institute of Genetic Resources of the University of Banja Luka.

Expert opinion on the research of biodiversity was issued by the Republic Institute for Protection of cultural, historical and nature heritage of Republic of Srpska (No. 30 / 625-723 / 18, 09.10. 2018th year; number 07/1.30/625-020/19, dated 23.1. 2019).

\section{References:}

[1] FÜreder, L., Gherardi, F., Souty-Grosset, C. (2010): Austropotamobius torrentium (errata version published in 2017). The IUCN Red List of Threatened Species 2010: e.T2431A121724677. Downloaded on 01 October 2019 
[2] Hogger, J.B. (1988): Ecology, population biology and behaviour. In: Holdich, D.M. and Lowery, R.S. (eds.) Freshwater crayfish: Biology. Management and Exploitation. The University press, Cambridge, 114-144.

[3] JURKOviĆ, T. (2016): Populacijske značajke potočnog raka Austropotamobius torrentium (Schrank, 1803) u potoku Dolje. Diplomski rad, Prirodoslovno-matematički fakultet, Zagreb. [in Croatian with English summary]

[4] LAURENT, P.J. (1988): Austropotamobius pallipes and A. torrentium, with observations on their interactions with other species in Europe. In: Holdich, D.M. \& R.S. Lowery (eds.), Freshwater Crayfish: Biology, Management and Exploitation. Chapman \& Hall, London: 341-346.

[5] Maguire, I. (2010): Slatkovodni rakovi, Priručnik za inventarizaciju i praćenje stanja, Državni zavod za zaštitu prirode, Zagreb, 44. [in Croatian]

[6] Maguire, I., ERBEn, R., KlobuČAr, G.I.V., LAJTner, J. (2002): A year cycle of Austropotamobius torrentium (Schrank) in streams on Medvednica mountain (Croatia) Bulletin Francais de Pêche et Pisciculture 367: 943-957. doi: 10.1051/kmae:2002077

[7] Maguire, I., Gottstein-MatoČEC, S. (2004): The distribution pattern of freshwater crayfish in Croatia. Crustaceana 77 (1): 25-49. doi: 10.1163/156854004323037874

[8] OBRADOVić, J. (1988): Slatkovodni rakovi. Ribar. Jugoslavija 43: 55-59. [in Serbian with English summary].

[9] RAJČEVIĆ, V., CRNOGORAC B.Č., (2011): Rijeka Vrbanja - fiziogena svojstva sliva i riječnog sistema, monografija. „Art Print“", 277. [in Serbian]

[10] RAJKOVIĆ, M. (2012): Distribucija, filogenija, ekologija i konzervacija rakova iz familije Astacidae na području Crne Gore. Doktorska disertacija, Prirodno-matematički fakultet, Kragujevac. [in Serbian with English summary]

[11] Simić, V., Petrović, A., Rajković, M., Paunović, M. (2008): Crayfish of Serbia and Montenegro - The population status and the level of endangerment. Crustaceana 81 (10): 1153-1176. doi: 10.1163/156854008X374496

[12] Souty-Grosset, C., Holdich, D.M., NoËL, P.Y., Reynolds, J.D., HafFner, P. (2006): Atlas of crayfish in Europe. Muséum national d'Histoire naturelle, Paris, France, 187.

[13] Streissl, F., HöDL, W. (2002): Growth, morphometrics, size at maturity, sexual dimorphism and condition index of Austropotamobius torrentium Schrank. Hydrobiologia 477 (1-3): 201-208. doi: 10.1023/A:1021046426577

[14] TrožIĆ-BorovaC, S. (2012): Distribucija bjelonogog raka Austropotamobius pallipes (Lereboullet,1858) species complex (Astacoidea Latreille, 1802; Astacidae Latreille, 1802) u Bosni i Hercegovine. Zbornik radova "Struktura i dinamika ekosistema Dinarida - stanje, mogućnosti i perspektive. Posebno izdanje CXLIX. Akademija nauka Bosne $i$ Hercegovine. Srajevo 23: 153-166. [in Serbian with English summary]

[15] TROŽı́́-BOROVAC, S. (2011): Freshwater crayfish in Bosnia and Herzegovina: the first report on their distribution. Knowledge and Management of Aquatic Ecosystems 401: 26. doi: $10.1051 / \mathrm{kmae} / 2011048$

[16] Trožıć-Borovac, S., Deljanin, L., DaUtBašić, M. (2007): Ekološko-biosistematske karakteristike potočnog raka Austropotamobius torrentium (Shrank, 1803.) iz Nahorevskog potoka. Radovi Šumarskog fakulteta, 1, Univerzitet u Sarajevu: 39-55. [in Serbian with English summary]

[17] Vuković, T.N., Guzina, N., Vuković, D, Seratlić, E. Đurović, SofradžiJa, A. (1978): Problemi razvoja biosistematskih istraživanja slatkovodnih riba u Bosni i Hercegovini. Godišnjak Biološkog Instituta Univerziteta u Sarajevu 31: 207-211. [in Serbian with English summary]

[18] Westman, K., Pursiainen, M., Wilkman, R. (1978): A new folding trap model which prevents crayfish from escaping. Freshwater Crayfish 4 (1): 235-242. 